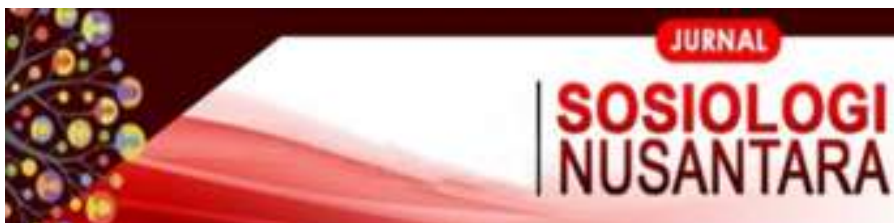

https://ejournal.unib.ac.id/index.php/jsn
DOI ://doi.org/10.33369/jsn.5.2.171-183

\title{
EKSISTENSI DRIVER OJEK ONLINE WANITA SEBAGAI BENTUK KESETARAAN GENDER
}

\section{EXISTENCE OF WOMEN OJEK ONLINE DRIVER AS GENDER EQUALITY FORM}

\author{
Alif Fadzilatus Siti Arofah ${ }^{1}$, Yus'afin Taji Alam² \\ fadzilatusarofah10@gmail.com, afintaji@gmail.com
}

${ }^{12}$ Fakultas Ilmu Sosial, Universitas Negeri Malang

\begin{abstract}
Abstrak
Wanita sering diidentikkan dengan pekerjaan rumah dan dianggap tidak kuat untuk mengerjakan pekerjaan yang identik dengan laki-laki. Namun saat ini wanita sudah mulai menyadari bahwa stigma-stigma patriarki dikalangan masyarakat ini dapat dibantahkan. Hal ini menunjukkan mulai adanya kesetaraan gender yang secara tidak langsung disuarakan oleh wanita-wanita tersebut. Artikel ini membahas mengenai wanita yang bekerja sebagai pengemudi ojek online, apa yang membuat mereka mengambil pekerjaan sebagai pengemudi ojek dan kehidupan mereka saat menjadi pengemudi ojek online dengan menggunakan pendekatan studi fenomenologi. Sasaran penelitian ini adalah wanita-wanita yang memilih bekerja sebagai driver ojek online baik sebagai pekerjaan utama maupun pekerjaan sampingan. Metode yang digunakan berupa observasi, wawancara mendalam serta dokumentasi. Hasil dari penemuan di lapangan adalah beberapa wanita memilih menjadi driver ojek online sebagai bentuk dari kesetaraan gender serta mereka juga menganggap bahwa menjadi driver ojek online merupakan pekerjaan yang cukup mudah untuk dilakukan baik sebagai pekerjaan utama maupun sampingan. Salah satu faktor utama pendorong wanita memilih bekerja sebagai driver ojek online merupakan mereka memiliki tanggung jawab untuk menghidupi anak-anaknya karena saat ini sebagai single parent.
\end{abstract}

Kata Kunci : wanita, pekerjaan, gender, ojek online, driver

\begin{abstract}
Women are often identified with homework. and considered not strong enough to do work that is identical to men. But now women have begun to realize that patriarchal stigmas in this society can be refuted. This shows the existence of gender equality which was indirectly voiced by these women. This article discusses women who work as online motorcycle taxi drivers, what makes them take jobs as motorcycle taxi drivers and their lives when they are online motorcycle taxi drivers using a phenomenological study approach. The target of this research are women who choose to work as an online
\end{abstract}


motorcycle taxi driver both as a main job and a side job. The method used in the form of observation, in-depth interviews and documentation. The results of the findings in the field are that some women choose to become online motorcycle taxi drivers as a form of gender equality and they also consider that being an online motorcycle taxi driver is a fairly easy job to do either as a primary or a side job. One of the main factors driving women to choose to work as an online motorcycle taxi driver is that they have the responsibility to support their children because they are currently single parents.

Keywords: women, job, gender, taxi online, driver

\section{PENDAHULUAN}

Di era globalisasi saat ini, perkembangan teknologi yang semakin pesat menuntut masyarakat untuk mengikuti perkembangan yang ada. Selain itu, perkembangan tersebut juga memberikan kemudahan kepada masyarakat dalam membantu kehidupan sehari-hari, sehingga masyarakat kini lebih memilih untuk menggunakan hal-hal yang praktis. Teknologi dalam konteks jasa transportasi dapat mempengaruhi minat konsumen dan pelanggannya. Sekarang juga mulai berkembang transportasi umum yang menggunakan aplikasi atau biasa disebut dengan "Transportasi Online". Transportasi online itu sendiri adalah transportasi yang memanfaatkan teknologi (Oktaviani, 2019). Dengan pemanfaatan teknologi tersebut muncullah beberapa aplikasi yang ada di Indonesia seperti Grab dan Go-jek yang menjadi kosumsi publik sekarang ini. Dengan kemunculan aplikasi yang semakin diminati masyarakat tersebut, memicu terjadinya perluasan lapangan pekerjaan dibidang jasa ojek online tersebut. Perekonomian masyarakat menjadi semakin maju meskipun kebutuhan masyarakat pun semakin meningkat. Kebutuhan masyarakat dilihat dari presentasi meningkatnya penggunaan aplikasi ojek online yang sangat diminati masyarakat. Berdasarkan survei yang terbaru untuk pengguna ojek online yang dilakukan lembaga riset ecommerceIQ (eIQ) yang dipublikasikan pertengahan Februari 2018, Go-Jek ternyata masih menjadi favorit masyarakat Indonesia dalam memilih transportasi berbasis aplikasi daring. Sebanyak 56\% responden memilih menggunakan Go-Jek setiap harinya, 33\% memilih Grab, dan hanya 8\% untuk Uber. Survei ini menghitung suara apabila responden pernah menggunakan layanan transportasi berbasis aplikasi tersebut. Dilihat dari data statistik tersebut bahwasannya tingkat penggunaan aplikasi diminati masyarakat karena masyarakat memiliki kemudahan untuk mengakses tersebut, melihat pasar penggunaan aplikasi ojek online yang semakin berkembang dan sudah 
mendapat kepercayaan dari masyarakat. Kemunculan transportasi aplikasi ojek online pun juga sebagai lapangan pekerjaan bagi masyarakat lainnya.

Kini masyarakat menggunakan transportasi online dalam kehidupannya seharihari, sehingga keberadaan transportasi online sangat dibutuhkan untuk menunjang mobilisasi yang dituntut cepat. Dibalik pesatnya pertumbuhan transportasi online saat ini, terdapat kontruksi sosial yang bermunculan dari para drivernya sendiri. Kontruksi sosial yang menggambarkan para driver ojek online didominasi oleh kaum laki-laki sehingga muncul dominasi patriarki dalam konsep kontruksi sosial karena lingkungan masyarakat selalu berasumsi bahwa pekerjaan yang berkaitan dengan kegiatan yang didominasi oleh kaum pria/maskulin dimana pekerjaan seperti berkendara, menjemput dan mengantarkan orang dari satu tujuan ke tujuan yang lain dan sering terkena debu kotor kendaraan dan setiap hari selalu bersinggungan dengan jalanan dan padatnya orang berkendara, merupakan hal profesi yang bisa dilakukan oleh pria/maskulin (Rafidan, 2019). Meskipun demikian, terdapat para wanita yang memilih menjadi driver ojek online sebagai pekerjaan mereka, dengan kontruksi sosial yang bahwasannya profesi tersebut merupakan profesi maskulin tidak menyudutkan niat para driver ojek online wanita untuk terus mencari nafkah dan memperjuangkan keberadaannya di lingkungan sosial untuk tetap mencari kesejahteraan hidup dengan bekerja sebagai driver ojek online meskipun perlu usaha yang cukup untuk wanita ini untuk menunjukkan keberadaan wanita mampu melakukan profesi maskulin tersebut, dengan dominasi laki-laki yang cukup banyak dalam pekerjaan driver ojek online eksistensi wanita merupakan capaian mereka untuk tetap berusaha untuk memenuhi kebutuhan hidup mereka sehingga dapat diartikan eksistensi sebagai pemikiran manusia yang dimanfatkan keberadaannya dan mengatasi seluruh pengetahuan yang objektif. Berdasarkan pemikiran tersebut, manusia dapat menjadi dirinya sendiri dan menunjukkan bahwa dirinya adalah makhluk eksistensi dan keberadaannya diakui dan dikenali (karls jaspers, 1985). Dengan eksistensi tersebut dapat mengubah pola konstruksi masyarakat sehingga ruang kesetaraan mereka dapat diterima oleh masyarakat khususnya para driver ojek konvensional atau ojek pangkalan. 
Ruang kesetaraan sendiri disimbolkan kedalam bentuk gender diartikan sebagai konstruksi sosiokultural yang membedakan karakteristik maskulin dan feminim. Moore mengemukakan bahwa gender berbeda dari seks dan jenis kelamin laki-laki dan perempuan yang bersifat biologis. Istilah gender dikemukakan oleh para ilmuwan sosial dengan maksud untuk menjelaskan perbedaan perempuan dan laki-laki yang mempunyai sifat bawaan (ciptaan Tuhan) dan bentukan budaya (konstruksi sosial). Gender adalah perbedaan peran, fungsi, dan tanggungjawab antara laki-laki dan perempuan yang tercipta dari hasil konstruksi sosial masyarakat dan dapat berubah sesuai dengan perkembangan jaman dan kemajuan ilmu pengetahuan (Abdullah, 2003: 19). Meskipun problematika driver ojek online sangat kompleks, sehingga masuk ke dalam pandangan kontruksi sosial, profesi tersebut tidak hanya dilakukan oleh para kaum lelaki saja.

Peneliti menemukan fenomena di lingkungan sosial mengenai eksistensi driver ojek online yang dilakukan oleh para perempuan. Hal tersebut menjadi menarik diperbincangkan karena stereotip yang ada di masyarakat sendiri beranggapan bahwa biasanya profesi tersebut hanya dilakukan oleh para kaum lelaki, dan biasanya para kaum perempuan tidak cocok melakukan pekerjaan yang ada di lapangan seperti menjadi driver ojek online. Stereotip bahwa perempuan tidak cocok bekerja di lapangan karena pekerjaan di lapangan didominasi pekerjaan berat dan harus dilakukan oleh setiap laki-laki, sudah menjadi pemikiran mendasar di lingkungan sosial masyarakat. Stereotip yang terbangun dikehidupan sosial masyarakat tidak lepas dari peran budaya dan tradisi yang selama ini sudah diakui keberadaan pola pikir yang mendasar dimasyarakat (Rokhmansyah, 2016:1). Perempuan dianggap hanya cocok untuk mengurus anak dan rumah tangga, tetapi dengan adanya tuntutan kehidupan yang semakin meningkat saat ini, stereotip tersebut banyak disanggah oleh kaum perempuan. Mereka memilih untuk tidak hanya mengurus anak dan rumah tangga, tetapi juga bekerja. Pekerjaan yang dipilih pun tidak selalu pekerjaan yang dianggap cocok untuk dilakoni perempuan, tetapi mereka juga memilih menjalani pekerjaan yang dianggap tabu untuk dikerjakan oleh kaum perempuan.

Emansipasi wanita yang kian lama kian digiatkan mendorong para kaum perempuan untuk menyetarakan keberadaannya dengan kaum laki-laki. Kaum perempuan merasa memiliki kekuatan yang setara dengan laki-laki sehingga mereka 
beranggapan perempuan juga berhak memiliki kapasitas multi peran dalam kehidupan sosial kultural masyarakat. Mereka berusaha memperjuangkan haknya agar tidak dibedakan dengan laki-laki. Salah satunya dalam menjalani sebuah profesi yang dipilih oleh perempuan itu sendiri dan sebagian kalangan perempuan bisa melakukannya. Diambil dari skripsi Peran Ganda Perempuan pada Ibu Bekerja di Desa Pakembinangun, Pakem, Sleman, Yogyakarta oleh Eka Puspitasari (2016), digambarkan mengenai apakah alasan yang menguatkan perempuan untuk memilih bekerja dan bagaimana perempuan memanfaatkan waktu untuk memerankan peran gandanya di rumah dengan perannya sebagai wanita karier. Hal tersebut yang memberikan peneliti gambaran mengenai bagaimana perempuan memutuskan untuk memilih bekerja dibandingkan hanya menjadi ibu rumah tangga di rumah.

Diambil dari jurnal fenomena kemiskinan dari prespektif kepala rumah tangga perempuan miskin (studi fenomonologi tentang makna dan penyebab, serta strategi penanggulangan feminisasi kemiskinan di desa wonorejo, Kecamatan Singosari, Kabupaten Malang) oleh nur rois ahmad sanggar kanto dan edi susilo (2015). Bagaimana gambaran bahwasannya permasalahan rumah tangga yang kompleks seharusnya diselesaikan oleh kepala rumah tangga tentunya dalam hal kemiskinan dan bagaimana hal ini harus diselesaikan oleh kepala rumah tangga yaitu perempuan. Dan selanjutnya dalam jurnal studi fenomologi pengemudi ojek online perempuan di kota bandung dalam kajian feminisme oleh irma verasatiwi dan retno wulan (2018). Bahwasannya dalam jurnal tersebut menganalisis bahwa hal-hal yang melatarbelakangi sebagai profesi ojek online dikontruksi oleh identitas diri yang berkaitan dengan motivasi dalam dirinya. Dan masyarakat belum sepenuhnya menerima keberadaan driver ojek online.

Dengan latar belakang yang berbeda-beda yang dimiliki oleh setiap orangnya, mereka berusaha menunjukkan eksistensinya dalam lingkungan sosial agar dianggap mampu untuk menjalani sebuah profesi yang setara dengan laki-laki. Identifikasi masalah dalam penelitian ini adalah bagaimana latar belakang yang melandasi para driver ojek online perempuan ini memilih untuk menjalani profesi tersebut, serta 
176 I Alif Fadzilatus Siti Arofah, Yus'afin Taji Alam

Eksistensi Driver Ojek Online Wanita Sebagai Bentuk Kesetaraan Gender

bagaimana para driver ojek online perempuan ini mengkonstruksikan dirinya di lingkungan masyarakat.

\section{METODE PENELITIAN}

Dengan kondisi yang ada di lapangan dan data yang telah didapatkan oleh penulis, artikel ini membahas tentang mengenai keberadaan pengemudi ojek online wanita yang ada diantara banyaknya pengemudi ojek online pria. Penelitian ini mengambil pendekatan dengan cara studi fenomenologi transcendental dengan menyampingkan prasangka peneliti mengenai adanya pengemudi ojek online wanita dengan menggunakan metode deskriptif. Menurut Mardalis (2008:26) metode deskriptif adalah upaya pendeskripsian kondisi-kondisi yang sekarang ini terjadi atau ada berupa fakta yang terjadi. Metode deskriptif digunakan untuk menggambarkan secara rinci realitas secara empiris sesuai dengan fenomena dan fakta yang terjadi dalam penelitian. Fokus dari penelitian ini ada pada driver ojek online wanita yang ada di Kota Malang, dengan teknik pengumpulan data berupa wawancara dengan para pengemudi wanita dan dalam menyimpan dokumentasi menggunakan alat perekam suara melalui ponsel yang ditranskrip dan catatan kecil. Menurut Moleong (2001: 161) dokumentasi dalam suatu penelitian dapat dibuat untuk menafsirkan, menguji bahkan meramal objek kajian yang diteliti. Dalam penelitian ini kehadiran penulis di tempat adalah menghubungi langsung para informan terlebih dahulu untuk menanyakan kesediaannya untuk menjadi informan, informan yang dipakai bukan dalam bentuk komunitas driver wanita melainkan individu-individu.

Penggalian data dimulai dengan mewawancarai satu driver wanita dan meminta tolong pengemudi wanita tersebut untuk memberikan kontak kenalannya yang juga merupakan driver wanita yang lain. Dalam mengelola data yang telah didapatkan, penulis membaginya dalam beberapa tahapan. Tahap pertama, data dimulai dari penelitian kecil yang telah tersusun sebelumnya. Tahap kedua, data yang telah diperoleh dari kegiatan wawancara dengan informan dan data-data lainnya dari lokasi penelitian diolah dan diberi kode tertentu. Tahap ketiga, setelah data tersebut diolah, peneliti melakukan pemeriksaan ulang terhadap data yang telah didapatkan sebelumnya, apakah data tersebut dapat diakui keabsahannya atau tidak dengan cara membandingkan data yang diterima dari nara sumber asli dengan nara sumber lainnya. Tahap akhir adalah 
analisis data, dibagian ini berisikan jawaban dari pertanyaan-pertanyaan yang telah dirumuskan.

\section{PEMBAHASAN}

\section{Latar Belakang Perempuan Menjadi Driver Ojek Online}

Ojek online sangat populer dalam beberapa saat ini, tentunya hal ini berdampak positif dan negatif bagi para penggunanya. Ojek online dapat diartikan sebagai sebuah inovasi yang ada di era saat ini yang muncul akibat adanya kemajuan teknologi (Azzam, 2018). Seperti yang kita ketahui, dampak positif dari adanya ojek online adalah tersedianya lapangan pekerjaan sebagai driver yang tidak memandang apakah pekerjaan tersebut harus dilakukan oleh laki-laki saja, namun perempuan juga bisa menjadi driver ojek online.

Beberapa perempuan memilih bekerja sebagai driver ojek online karena di era yang serba modern ini kebutuhan hidup semakin meningkat di mana tingkat lapangan pekerjaan yang tergolong harus bersaing dengan yang lain untuk mendapatkannya, sehingga perempuan-perempuan tersebut akan berusaha dengan sekuat tenaga untuk mencari nafkah namun juga dengan cara memanfaatkan kemajuan teknologi yang didukung dengan munculnya GOJEK pada tahun 2015 kemudian disusul GRAB dan UBER di tahun 2017 (Indriyani:2018). Hasil di lapangan menunjukkan bahwa sebagian besar perempuan yang menjadi driver ojek online adalah perempuan yang menjadi tulang punggung keluarga karena single parent dan harus memenuhi kebutuhan anak. Menjadi driver ojek online biasanya digunakan sebagai sampingan jika perempuan-perempuan tersebut sedang memerlukan dana yang lebih karena tuntutan suatu hal. Selain menjadi pekerjaan sampingan, driver ojek online juga menjadi pekerjaan utama beberapa wanita.

Driver ojek online menjadi pilihan beberapa kaum perempuan karena pekerjaan ini tidak perlu mengeluarkan modal banyak dan cukup mudah dalam pengerjaannya, tidak ditentukan oleh waktu dan bisa dilakukan kapan saja dimana saja. Pekerjaan ini cukup ramah bagi perempuan-perempuan yang memiliki sakit tertentu jika bekerja terlalu keras, maka dari itu menjadi driver ojek online dirasa pilihan yang tepat. Selain 
itu, menjadi driver ojek online juga memiliki keuntungan yang lumayan untuk memenuhi kebutuhan sehari-hari meskipun harus melewati teriknya sinar matahari. Seiring semakin majunya perkembangan ekonomi dunia, tidak menutup kemungkinan bahwa kebutuhan setiap individu juga semakin banyak.

\section{Kesetaraan Gender terkait dengan Driver Ojek Online Wanita}

Gender muncul sebagai bentuk penjelasan bahwa laki-laki dan perempuan memiliki 2 sifat, yakni sifat bawaan yang lahir dari Tuhan serta sifat yang terbentuk oleh faktor-faktor budaya dan lingkungan yang dipelajari sejak kecil (Puspitawati, 2013: 1). Dengan adanya istilah gender ini dapat memudahkan serta membuka mata masyarakat bahwa terdapat sifat-sifat yang sebenarnya bisa dilakukan baik oleh lakilaki maupun perempuan serta dapat membuat kita lebih mencerna kembali mengenai pembagian peran yang selama ini dianggap lebih condong ke laki-laki maupun perempuan. Di era modern saat ini, banyak perempuan yang sudah cukup berani untuk mengutarakan kesetaraan gender serta persamaan hak dengan arti untuk meningkatkan sumber daya manusia masyarakat Indonesia (Wibowo: 2011). Menurut Sukesi (1991) bahwa perempuan memiliki 2 peran yakni tradisi serta transisi. Peran tradisi adalah peran ketika perempuan menjadi seorang istri, seorang ibu, dan pengurus rumah tangga. Sedangkan peran transisi adalah peran ketika perempuan menjadi tenaga kerja, manusia pengembangan serta bagian dalam masyarakat.

Dalam tulisan ini yang membahas mengenai driver ojek online wanita di Malang sebenarnya merupakan salah satu bentuk atau sikap perempuan-perempuan yang menyatakan bahwa menjadi seorang ojek bukan hanya bisa dilakukan oleh lakilaki, namun juga perempuan meskipun laki-laki tetap mendominasi sebagai driver ojek online. Penemuan di lapangan menunjukkan bahwa perempuan-perempuan yang memilih menjadi driver ojek online menganggap bahwa menjadi ojek bukan hanya bisa atau harus dilakukan oleh laki-laki, namun juga perempuan. Mereka menyadari bahwa sebenarnya perempuan memang bisa berada dalam posisi apapun selagi perempuan itu mampu.

Konsep kesetaraan gender juga menjelaskan mengenai peran ganda, yang dalam hal ini dilakukan oleh perempuan. Seperti penjelasan di atas bahwa perempuan yang memiliki pekerjaan sebagai driver ojek online juga tetap melakukan perannya sebagai ibu dari anak-anaknya serta mengurus rumah tangga di rumah. Sebagian besar 
perempuan yang bekerja sebagai driver ojek online ini merupakan single parent yang artinya sudah tidak memiliki sosok suami dalam keluarganya sehingga memiliki tanggungan berupa harus tetap menghidupi keluarganya terutama anak-anaknya.

\section{Pengalaman Selama Menjadi Driver Ojek Online}

Perempuan-perempuan yang bekerja sebagai driver ojek online mengaku mendapat berbagai macam pengalaman ketika berhadapan dengan penumpang. berbagai macam penumpang sudah pernah dirasakan driver-driver tersebut, seperti penumpang yang dermawan biasanya akan memberi uang lebih untuk driver, penumpang yang tidak sabaran biasanya akan meng-cancel pesanan karena dianggap menunggu terlalu lama, terkadang bertemu dengan penumpang yang aktif mengajak berbicara sepanjang perjalanan, namun tidak jarang juga menemukan penumpang yang sedikit cuek sehingga tidak ada obrolan selama perjalanan.

Selain pengalaman dengan penumpang, driver perempuan ini juga mengaku mendapat pengalaman ketika membelikan makanan bagi customer dimana terkadang makanan yang dipesan ternyata habis dan akhirnya pesanan di-cancel oleh customer. Namun tidak jarang juga driver menemukan customer yang meskipun makanan yang dipesan habis tetapi tetap memesan dengan menu yang lain sehingga sang driver tidak sampai kehilangan customer-nya. Juga pengalaman ketika bertemu driver lain yang laki-laki, tidak pernah ada konflik atau semacamnya karena mereka beranggapan bahwa sama-sama mencari rezeki melalui aplikasi ojek online. Menjadi driver ojek online memang memerlukan kesabaran ekstra dan telaten dalam menghadapi berbagai orang yang berbeda-beda latar belakang dan tentunya karakter.

Beberapa portal berita online kerap membahas mengenai driver ojek online perempuan yang terkadang memiliki kendala dengan para customer mereka. Salah satu contohnya seperti yang dibahas oleh portal berita tempo mengenai seorang driver ojek online wanita yang menghidupi keempat anaknya, saat bekerja ia terkadang membawa anak bungsunya yang masih berumur 1 tahun karena ketiga kakaknya tengah bersekolah. Tidak hanya membawa anak bungsunya saja, ada pula tantangan yang harus dihadapi oleh Penny seperti para customer yang membatalkan orderan dengan alasan risih, takut, bahkan kasihan. Yang terparah adalah ketika customer tidak membayar 
jasanya, bahkan Penny pernah menunggu selama setengah jam di depan tempat tujuan customer tersebut.

Dalam kesehariannya, driver perempuan ini mendapatkan penghasilan sekitar Rp 100.000-250.000 bagi yang menjadikan driver ojek online sebagai pekerjaan utama dan berpenghasilan Rp 50.000-150.000 bagi yang menjadikan pekerjaan ini sebagai sampingan ketika selesai mengerjakan pekerjaan utama. Biasanya perempuanperempuan yang menjadikan driver ojek online sebagai pekerjaan sampingan akan dilakukan ketika gaji pekerjaan utama untuk satu bulan dirasa kurang mencukupi, namun jika gaji tersebut dirasa mencukupi maka perempuan-perempuan tersebut memilih untuk mengurus anak di rumah. Sebagai perempuan yang disibukkan dengan anak, beberapa driver perempuan memilih menitipkan anaknya kepada sanak saudara atau teman ketika sedang melakukan pekerjaan sebagai driver ojek online, hal ini terjadi jika sang driver memiliki anak yang masih tergolong di bawah umur.

\section{Pandangan Mengenai Adanya Driver Ojek Online Perempuan}

Pandangan driver ojek online terhadap sesama driver wanita lainnya adalah tidak pernah mempermasalahkan meskipun driver ojek identik dengan pekerjaan lakilaki karena selagi pekerjaan yang dilakukan positif dan bisa saling membantu satu sama lain maka hal ini bukan suatu permasalahan. Sebagai sesama driver sudah selayaknya saling mendukung, bukan menjatuhkan karena rezeki setiap orang sudah mendapat jatah sendiri-sendiri. Mereka menganggap hal ini adalah bentuk kesetaraan gender dimana pekerjaan yang identik dengan laki-lakipun bisa dilakukan oleh perempuan. Beberapa perempuan memilih untuk membentuk komunitas driver ojek online wanita sebagai bentuk eksistensi perempuan yang menjadi driver tersebut, namun beberapa yang lain juga memilih untuk tidak mengikuti komunitas-komunitas tersebut karena lebih memilih untuk berkumpul bersama keluarga selepas bekerja.

Pandangan driver ojek online laki-laki terhadap driver perempuan tidak jauh beda dengan pandangan sebelumnya bahwa mereka tetap akan saling mendukung selagi tidak ada hal negatif yang dilakukan. Beberapa driver laki-laki mengaku kagum dan salut terhadap perempuan-perempuan yang bekerja keras menjadi tulang

punggung keluarga untuk mencari nafkah demi anak-anaknya bahkan dilakukan dengan cara bekerja yang biasanya dilakukan oleh laki-laki. Bentuk dukungan biasanya berupa sapaan-sapaan ringan ketika bertemu sesama driver di jalan ataupun 
ketika beristirahat sambil menunggu pesanan datang.

Sedangkan pandangan masyarakat terhadap driver ojek online perempuan adalah sebagai bentuk kemajuan perempuan dengan sifat mandiri dan pekerja keras sehingga menutup mata masyarakat mengenai wanita yang cenderung dikenal lembut dan memilih berdiam di rumah dan mengurus anak. Juga sebagai bentuk perempuan yang menjadi orang tua yang bertanggung jawab terhadap kelangsungan hidup keluarganya di tengah arus globalisasi yang memiliki perkembangan secara pesat. Selain itu, di tengah persaingan lapangan pekerjaan yang sangat kuat ini, masih terdapat perempuanperempuan yang mampu bertahan dan bahkan bisa memenangkan persaingan ini. Tentunya dengan perkembangan teknologi yang semakin canggih ini diharapkan dapat menumbuhkan banyak lapangan pekerjaan bagi seluruh masyarakat dunia.

\section{KESIMPULAN}

Semakin majunya perkembangan teknologi, dirasa semakin memudahkan masyarakat dalam memajukan hidupnya. Salah satu hasil dari kemajuan teknologi saat ini adalah adanya ojek online di kawasan Indonesia, salah satunya di Malang. Ojek online menjadi salah satu pekerjaan yang sangat identik dengan kaum laki-laki, menurut stigma masyarakat Indonesia. Namun hal ini dibantah oleh munculnya driver ojek online perempuan di beberapa daerah di Indonesia. Menjadi driver ojek online bagi beberapa perempuan dianggap menjadi hal yang wajar karena saat ini sudah banyak masyarakat yang mulai menyadari akan kesetaraan gender karena kita tahu bahwa Indonesia sangat menganut budaya patriarki. Feminisme memandang driver ojek online perempuan ini sebagai bentuk penyuaraan oleh perempuan bahwa tidak selamanya pekerjaan yang selama ini identik dengan laki-laki mustahil untuk dilakukan oleh perempuan.

Penemuan di lapangan menunjukkan bahwa sebagian besar latar belakang perempuan memilih bekerja sebagai driver ojek online adalah karena posisinya yang saat ini sebagai single parent dan harus menghidupi keluarganya serta memenuhi kebutuhan rumah tangganya terutama untuk anak. Salah satu pengalaman berbeda yang didapat oleh driver ojek online perempuan adalah beberapa customer yang memilih 
untuk membonceng sang driver karena terdapat perasaan empati terhadap driver wanita. Pandangan driver ojek online terhadap sesama driver wanita lainnya adalah tidak pernah mempermasalahkan meskipun driver ojek identik dengan pekerjaan laki-laki karena selagi pekerjaan yang dilakukan positif dan bisa saling membantu satu sama lain maka hal ini bukan suatu permasalahan.

\section{DAFTAR PUSTAKA}

Andebar, Wisnu. 2018. Kisah Driver Gojek Wanita: Bawa Anak hingga Penumpang Tak

Tempo.co .(https://www.google.com/amp/s/otomotif.tempo.co/amp/1150339/kisa h-driver-gojek-wanita-bawa-anak-hingga-penumpang-tak-bayar), diakses $1 \mathrm{Mei}$ 2019.

Azzam, Abdurrofi A. 2018. Bisnis Ojek Online. Kompasiana. (Online), (https://www.kompasiana.com/abdurrofiabdullah/5c0fe72943322f14247dab34/bis nis-ojek-online), diakses 1 Mei 2019.

Fakih, M. (2006). Analisis Gender dan Transformasi Sosial. Yogyakarta: Pustaka Pelajar.

Hamersma. Harry, Filsafat Eksistensial Karl Jaspers, Jakarta: Gramedia, 1985. http://wacana.ub.ac.id/index.php/empati/article/view/15006/1 405 diakses 2 mei 2019.

Indriyani, Fintri. 2018. Pemilihan Ojek Online Bagi Wanita Karir Menggunakan Analytic Hierarchy Process. Journal of Information System. Vol. 3/2018 (1) 2228. DOI: https://doi.org/10.33633/joins.v3i1.1878.

Larasati, Tania. Tidak ada tahun. Stereotif terhadap perempuan pengemudi transportasi umum berbasis online di jakarta timur. Surabaya: departemen antropologi fakultas ilmu sosial dan ilmu politik universitas airlangga, surabaya. (E-jurnal) http://ejurnal3.undip.ac.id/index.php/empati/article/view/15006/1 diakses pada 2 mei 2019.

Mardalis. 2008. Metode Penelitian Proposal. Jakarta:BumiAksara.

Moelong, Lexy. 2001. Metode Penelitian Kualitatif. Bandung: Rosdakarya.

No name. 2015. 5 Pendekatan dalam Penelitian Kualitatif. (online). (https://www.researchgate.net/publication/293821955_feminisme_sebagai_teori_ dan_gerakan_sosial_di_indonesia), diakses 13 Maret 2019.

Oktaviani, Dian Catur. 2019. Analisis Perbandingan Kualitas Pelayanan, Harga dan Kepuasan Konsumen Pengguna Layanan Go-Jek dan Grab. Skripsi diterbitkan. Jurusan Ekonomi Syariah Fakultas Ekonomi dan Bisnis Islam Institut Agama Islam Negeri Purwokerto. 
Puspitawati, H. 2012. Gender dan Keluarga: Konsep dan Realita di Indonesia. PT IPB Press. Bogor.

Rafidan, Hilman R. 2018. Kontruksi Sosial Ojek Online Perempuan. Skripsi diterbitkan. Program Studi Sosiologi Fakultas Ilmu Sosial dan Ilmu Politik Universitas Airlangga Surabaya.

Rokhmansyah, Alfian. 2016. Pengantar Gender dan Feminisme. Yogyakarta: Garudhawaca.

Rokhmansyah, Alfian. 2016. Pengantar Gender dan Feminisme. Yogyakarta: Garudhawaca.

Wibowo, Dwi Edi. 2011. Peran Ganda Perempuan dan Kesetaraan Gender. Jurnal Muwazah. Vol. 3/2011 (1). journal.iainpekalongan.ac.id/index.php/Muwazah/article/view/6 